\title{
Use of remotely sensed and field data to estimate the contribution of Ghilean glaciers to eustatic sea-level rise
}

\author{
Andrés Rivera, ${ }^{1,3}$ Gesar Aquña, ${ }^{1}$ Gino Gasassa, ${ }^{2,3}$ Francisca Bown ${ }^{1}$ \\ ${ }^{1}$ Departamento de Geografía, Universidad de Chile, Av. Marcoleta 250, Santiago, Chile \\ ${ }^{2}$ Instituto de la Patagonia, Universidad de Magallanes, Av. Bulnes 01855, Punta Arenas, Chile \\ ${ }^{3}$ Centro de Estudios Cientificos de Valdivia, Av. Arturo Prat 514, Valdivia, Chile
}

\begin{abstract}
A synthesis of glaciological studies carried out in Chile during recent decades is presented, including inventories and records of glacier variations, fluctuations of which are related to regional climate change and their contribution to eustatic sea-level rise. Based upon satellite imagery, aerial photographs and historical records, new data for 20 glaciers are presented. These new data are combined with previous records to cover the historical variations of 95 Chilean glaciers. Of these glaciers, only $6 \%$ show a net advance during the study period, $6 \%$ show no significant change, while $88 \%$ have retreated. The contribution of Chilean glaciers to eustatic sea-level rise has been estimated to be approximately $8.2 \%$ of the worldwide contribution of small glaciers on Earth during the last 51 years. Most of the glacier variations are thought to have been driven by a temperature increase, which has been documented by several stations in Chile. Anomalies in rainfall, and the decreasing trend in annual precipitation shown at a few stations, have probably also contributed to glacier recession. Based on observed climatic trends, it is expected that the glacier retreat will continue, that the mass balance will continue to show a negative trend and that thinning rates will increase. All of these changes will ultimately affect the availability of water resources in Chile that depend on glacierized basins.
\end{abstract}

\section{INTRODUGTION}

One of the most important consequences of global warming is the eustatic sea-level rise produced by the melting of mountain and other glaciers. Meier (1984) estimated that between 1900 and 1961 the contribution of mountain and other types of glaciers (ice caps and ice fields, but excluding the Antarctic and Greenland ice sheets) to global sea-level rise was $0.46 \mathrm{~mm} \mathrm{a}^{-1}$, with Andean glaciers located between $30^{\circ}$ and $55^{\circ} \mathrm{S}$, contributing $11.6 \%$ of the total.

For his calculation, Meier estimated that the surface area of the glaciers of the Andes $\left(30-55^{\circ} \mathrm{S}\right)$ was $31000 \mathrm{~km}^{2}$, which corresponds to $5.7 \%$ of the world's total glacierized area. However, our estimations indicate that the Chilean glaciers cover $20575 \mathrm{~km}^{2}$, and the Argentine glaciers cover nearly $3200 \mathrm{~km}^{2}$.

Analyzing Hielo Patagónico Norte and Sur (HPN and HPS; northern and southern Patagonia ice fields), Aniya (1999) estimated that their contributions to mean sea-level rise would reach $0.038 \mathrm{~mm} \mathrm{a}^{-1}$, or $8.3 \%$ of the total sea-level rise estimated by Meier.

Elsewhere in Chile, the few glaciers studied to date also show a clear recessional trend, but the volume of meltwater contributed to eustatic sea-level rise is presently unknown. In fact, the inventory of Chilean glaciers is still incomplete and there is only a single mass-balance record (Glaciar Echaurren Norte; see Fig. 1). Moreover, there are limited ice-thickness data, and very few glacier surface changes have been measured (Rivera and others, 2000).

This paper summarizes new data on thickness, frontal and areal variations from a large number of glaciers in
Chile. Based on these data and the previous work of Aniya (1999), the contribution of Chilean glaciers to global sea level is estimated.

\section{GHILEAN GLACIERS}

Until 1999, a total of 1682 glaciers in Chile outside Patagonia $\left(18-41^{\circ} \mathrm{S}\right)$ had been inventoried, with a total surface area of $1401 \mathrm{~km}^{2}$ (Rivera and others, 2000). In northern Chile, where the glacierized area is sparse, an inventory was carried out by Garín (1987). In central Chile, almost all of the glaciers have been inventoried under the direction of Dirección General de Aguas (DGA). Only the glaciers of the Río Itata basin (Fig. 1) have not yet been inventoried. Rivera and others (2000) estimated the surface area of the glaciers of this basin to be $15 \mathrm{~km}^{2}$.

South of $41^{\circ} \mathrm{S}$, only HPN and HPS have been inventoried: HPN was studied by Aniya (1988), based on 1:50000 scale maps compiled by Instituto Geográfico Militar (IGM) of Chile, aerial photographs and field studies. This ice field was divided into 28 major glaciers, with a total area of $4200 \mathrm{~km}^{2}$ of ice. HPS was studied by Aniya and others (1996), based on the earlier study by Lliboutry (1956) and the preliminary maps at a scale of 1:250000 from IGM; these maps were used by Aniya to georeference a 1986 Landsat Thematic Mapper (TM) image to compile the inventory. This ice field was divided into 48 major glaciers, covering an area of $11259 \mathrm{~km}^{2}$. Of these glaciers, 40 are estimated to be located in Chile, covering an area of $9659 \mathrm{~km}^{2}$.

Despite a number of studies during the last few decades, there are still glacier inventories missing in most of the region 


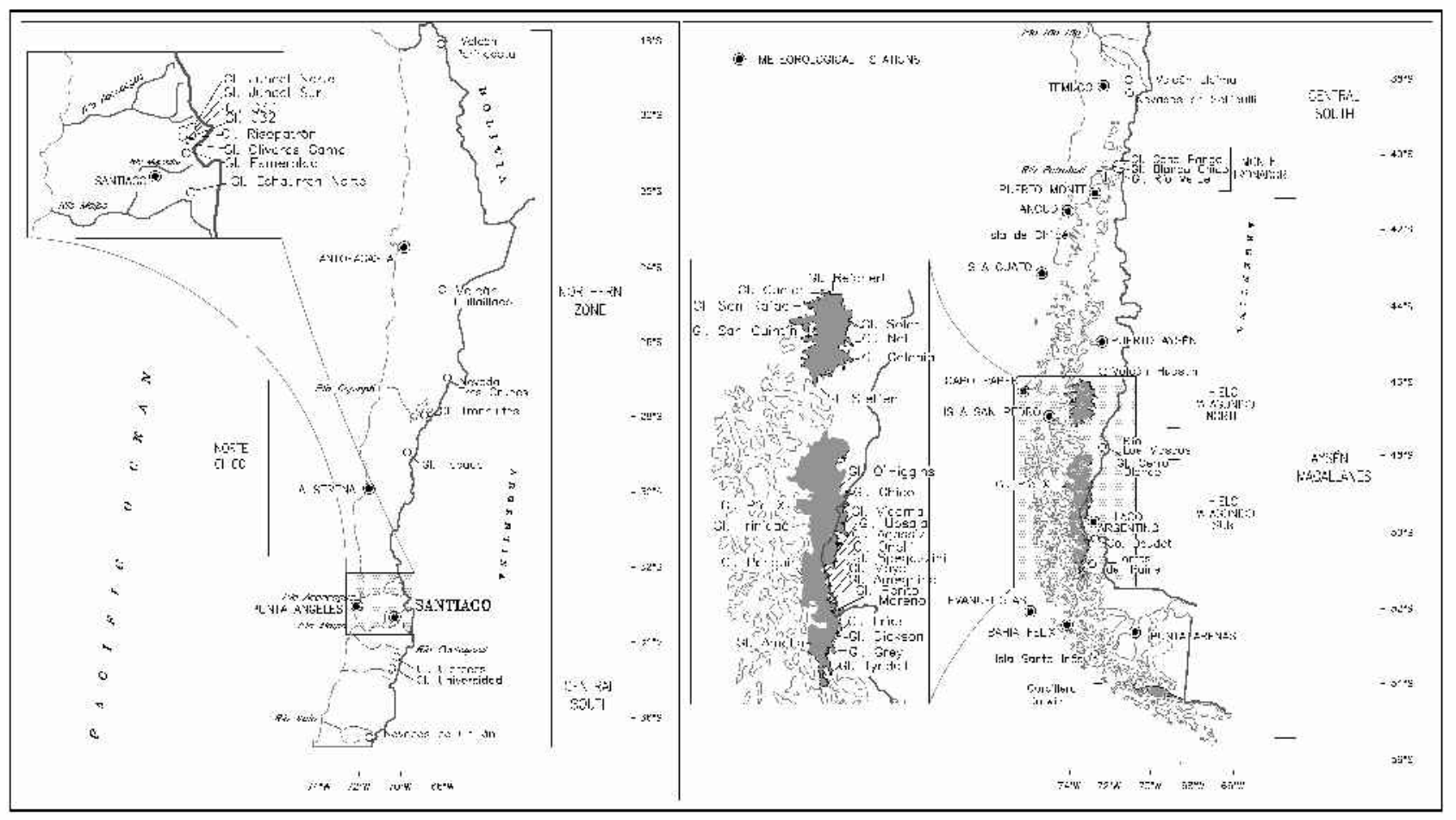

Fig. 1. Index maps showing the location of the glaciers and other geographic features discussed in the text. Gl., Glaciar.

of Aysén and Magallanes (Fig. 1), where a glacier area of approximately $5300 \mathrm{~km}^{2}$ has been estimated. For instance, Cordillera Darwin includes an estimated $2300 \mathrm{~km}^{2}$ (Lliboutry, 1998), and isla Santa Inés an estimated $250 \mathrm{~km}^{2}$ (Lliboutry, 1956). In the area surrounding HPS there are a significant number of small glaciers not yet inventoried and of which few studies have been undertaken. We estimate the total area of these glaciers to be $1500 \mathrm{~km}^{2}$.

Taking into account the inventoried glaciers in Chile outside Patagonia $\left(1401 \mathrm{~km}^{2}\right)$, Río Itata basin $\left(15 \mathrm{~km}^{2}\right)$, HPN $\left(4200 \mathrm{~km}^{2}\right), 40$ glaciers of HPS $\left(9659 \mathrm{~km}^{2}\right)$ and the estimated yet to be inventoried, glaciers of Aysén and Magallanes region $\left(5300 \mathrm{~km}^{2}\right)$, the total surface area covered by Chilean glaciers is $20575 \mathrm{~km}^{2}$.

\section{Glacier zones}

Chilean glaciers were divided into five large zones, depending not only on regional climatic and glaciological conditions, but also on existing inventories and other studies:

1. Northern Chile, from the Chile-Peru border $\left(18^{\circ} \mathrm{S}\right)$ to $32^{\circ} \mathrm{S}$. In this zone we have analyzed in detail Glaciares Tronquitos and Tapado (Fig. 1).

2. Central-south Chile $\left(32-41^{\circ} \mathrm{S}\right)$, which is almost completely inventoried. We have analyzed 13 glaciers in detail here.

3. Aysén and Magallanes $\left(41-56^{\circ} \mathrm{S}\right)$, including all of the glaciers not presently inventoried and little studied (Holmlund and Fuenzalida, 1995); under such conditions only general estimations of their behaviour can be made. We have analyzed in detail Glaciar del río Los Moscos and Trinidad (Fig. 1)

4. HPN: the main 28 glaciers inventoried by Aniya (1988) and analyzed in detail by Aniya (2001).

5. HPS-Chile: only the Chilean portion of HPS is considered in this study, which corresponds to 40 of the 48 glaciers inventoried by Aniya and others (1996). The ChileArgentina boundary in HPS is not well defined. Eight glaciers in HPS are assumed to have their surfaces mainly in Argentina, and are excluded from our analysis (Glaciares Upsala, Agassiz, Onelli, Spegazzini, Mayo, Ameghino, Moreno and Frias). We have analyzed in detail Glaciares Chico, Dickson and Amalia (Fig. 1).

\section{METHODOLOGY}

To estimate the volume of ice mass contributed to eustatic sealevel rise by Chilean glaciers, following the method employed by Aniya (1999), several parameters were considered for each zone: glacier surface, thickness, surface change, thinning rate and ice density.

\section{Frontal and surface variations}

Each glacier's frontal and surface variations were determined mainly through stereoscopic, vertical aerial photographs.

Table 1. Thickness estimation ordered by rank (source: Marangunic, 1979)

\begin{tabular}{cc}
\hline $\begin{array}{c}\text { Size rank } \\
\mathrm{km}^{2}\end{array}$ & $\begin{array}{c}\text { Mean thickness } \\
\mathrm{m}\end{array}$ \\
\hline $0-0.1$ & 5 \\
$0.11-0.5$ & 20 \\
$0.51-1.0$ & 40 \\
$1.01-2.00$ & 65 \\
$2.01-5.00$ & 90 \\
$5.01-10.00$ & 120 \\
$10.01-20.0$ & 155 \\
$>20.01$ & 200 \\
\hline
\end{tabular}


Table 2. Frontal fluctuations of Chilean glaciers (source: this work)

\begin{tabular}{|c|c|c|c|c|c|}
\hline Zone & Glacier & Location & Period & $\begin{array}{c}\text { Change in frontal distance } \\
\mathrm{m}\end{array}$ & $\begin{array}{l}\text { Frontal variation rate } \\
\qquad \mathrm{m} \mathrm{a}^{-1}\end{array}$ \\
\hline Northern & Tronquitos & $28^{\circ} 32^{\prime} \mathrm{S}, 69^{\circ} 43^{\prime} \mathrm{W}$ & $\begin{array}{l}1955-84 \\
1984-96\end{array}$ & $\begin{array}{l}-420 \\
-279\end{array}$ & $\begin{array}{l}-14 \\
-23\end{array}$ \\
\hline Central-south & Juncal Norte & $33^{\circ} 02^{\prime} \mathrm{S}, 70^{\circ} 06^{\prime} \mathrm{W}$ & $\begin{array}{l}1955-97 \\
1997-2000\end{array}$ & $\begin{array}{r}-170 \\
-12\end{array}$ & $\begin{array}{l}-4 \\
-4\end{array}$ \\
\hline Central-south & Juncal Sur & $33^{\circ} 05^{\prime} \mathrm{S}, 70^{\circ} 06^{\prime} \mathrm{W}$ & $1955-97$ & -2108 & -50 \\
\hline Central-south & Risopatrón & $33^{\circ} 08^{\prime} \mathrm{S}, 70^{\circ} 05^{\prime} \mathrm{W}$ & $1955-97$ & -530 & -13 \\
\hline Central-south & G30 & 33 08’ S, $7008^{\prime} \mathrm{W}$ & $1955-97$ & -517 & -12 \\
\hline Central-south & G32 & $3308^{\prime} \mathrm{S}, 7007^{\prime} \mathrm{W}$ & $1955-97$ & -527 & -13 \\
\hline Central-south & Olivares Beta & $33^{\circ} 08^{\prime} \mathrm{S}, 70^{\circ} 11^{\prime} \mathrm{W}$ & $1955-97$ & -898 & -21 \\
\hline Central-south & Olivares Gama & $33^{\circ} 08^{\prime} \mathrm{S}, 70^{\circ} 10^{\prime} \mathrm{W}$ & $1955-97$ & -623 & -15 \\
\hline \multirow[t]{4}{*}{ Central-south } & \multirow[t]{4}{*}{ Cipreses } & \multirow[t]{4}{*}{$34^{\circ} 33^{\prime} \mathrm{S}, 70^{\circ} 22^{\prime} \mathrm{W}$} & 1860-88 & -280 & -10 \\
\hline & & & 1888-1955 & -737 & -11 \\
\hline & & & $1955-68$ & -351 & -27 \\
\hline & & & $1968-97$ & -870 & -30 \\
\hline Central-south & Universidad & $34^{\circ} 42^{\prime} \mathrm{S}, 70^{\circ} 20^{\prime} \mathrm{W}$ & $1955-97$ & -760 & -18 \\
\hline \multirow[t]{5}{*}{ Central-south } & \multirow[t]{5}{*}{ Casa Pangue } & \multirow[t]{5}{*}{$41^{\circ} 08^{\prime} \mathrm{S}, 71^{\circ} 52^{\prime} \mathrm{W}$} & $1911-45$ & -172 & -5 \\
\hline & & & $1945-61$ & -512 & -32 \\
\hline & & & $1961-81$ & -367 & -18 \\
\hline & & & $1981-95$ & -732 & -52 \\
\hline & & & $1995-97$ & -134 & -67 \\
\hline \multirow[t]{4}{*}{ Central-south } & \multirow[t]{4}{*}{ Blanco Chico } & \multirow[t]{4}{*}{$41^{\circ} 09^{\prime} \mathrm{S}, 71^{\circ} 55^{\prime} \mathrm{W}$} & $1961-81$ & -236 & -12 \\
\hline & & & 1981-95 & -839 & -60 \\
\hline & & & $1961-95$ & -1075 & -32 \\
\hline & & & 1995-97 & -34 & -17 \\
\hline \multirow[t]{2}{*}{ Central-south } & \multirow{2}{*}{ Río Verde } & \multirow{2}{*}{$41^{\circ} 12^{\prime} \mathrm{S}, 71^{\circ} 50^{\prime} \mathrm{W}$} & 1961-81 & -362 & -18 \\
\hline & & & $1981-95$ & -70 & -5 \\
\hline \multirow[t]{2}{*}{ Aysén-Magallanes } & \multirow[t]{2}{*}{ Cerro Blanco } & \multirow[t]{2}{*}{$4820^{\prime} \mathrm{S}, 7215^{\prime} \mathrm{W}$} & $1945-75$ & -867 & -29 \\
\hline & & & $1975-97$ & -420 & -19 \\
\hline \multirow[t]{3}{*}{ Aysén-Magallanes } & \multirow[t]{3}{*}{ Trinidad } & \multirow[t]{3}{*}{$4925 \mathrm{~S}, 7345^{\prime} \mathrm{W}$} & $1945-86$ & 870 & 21 \\
\hline & & & $1986-95$ & 840 & 93 \\
\hline & & & $1995-2000$ & 245 & 49 \\
\hline \multirow[t]{3}{*}{ HPS-Chile } & \multirow[t]{3}{*}{ Chico } & $49^{\circ} 00^{\prime} \mathrm{S}, 73^{\circ} 04^{\prime} \mathrm{W}$ & $1945-75$ & -1560 & -52 \\
\hline & & & $1975-86$ & -275 & -25 \\
\hline & & & $1986-95$ & -153 & -17 \\
\hline HPS-Chile & Amalia & $50^{\circ} 57^{\prime} \mathrm{S}, 73^{\circ} 45^{\prime} \mathrm{W}$ & $1945-75$ & -8040 & -268 \\
\hline & & & 1975-86 & -197 & -18 \\
\hline & & & $1986-96$ & -450 & -45 \\
\hline HPS-Chile & Dickson & $50^{\circ} 47^{\prime} \mathrm{S}, 73^{\circ} 09^{\prime} \mathrm{W}$ & $1901-45$ & -1570 & -36 \\
\hline & & & $1945-75$ & -1214 & -40 \\
\hline & & & $1975-84$ & -1078 & -123 \\
\hline & & & 1984-95 & -409 & -44 \\
\hline & & & 1995-98 & -180 & -51 \\
\hline
\end{tabular}

Table 3. Glacier surface changes and normalization to 51 years in Chile (source: this work)

\begin{tabular}{|c|c|c|c|c|c|c|c|c|c|}
\hline \multirow[t]{2}{*}{ Zone } & \multirow[t]{2}{*}{ Glacier } & \multirow[t]{2}{*}{ Aspect } & \multirow[t]{2}{*}{ Study period } & \multirow{2}{*}{$\begin{array}{c}\text { Original } \\
\text { surface area } \\
\mathrm{km}^{2}\end{array}$} & \multirow{2}{*}{$\begin{array}{c}\text { Final surface } \\
\text { area } \\
\mathrm{km}^{2}\end{array}$} & \multirow{2}{*}{$\begin{array}{c}\text { Total area } \\
\text { change } \\
\mathrm{km}^{2}\end{array}$} & \multirow{2}{*}{$\begin{array}{c}\text { Lost-area ratio } \\
\quad \%\end{array}$} & \multirow{2}{*}{$\begin{array}{c}\text { Annual area } \\
\text { variation mean } \\
\mathrm{km}^{2} \mathrm{a}^{-1}\end{array}$} & \multirow{2}{*}{$\begin{array}{l}\text { Loss: } 51 \text { years } \\
\qquad \mathrm{km}^{2}\end{array}$} \\
\hline & & & & & & & & & \\
\hline Northern & Tronquitos & SW & $1955-84$ & 4.6 & 4.0 & -0.52 & -11.4 & -0.01 & -0.46 \\
\hline Central-south & Juncal Norte & $\mathrm{N}$ & $1955-97$ & 9.0 & 8.8 & -0.22 & -2.4 & -0.01 & -0.27 \\
\hline Central-south & Juncal Sur & $\mathrm{s}$ & $1955-97$ & 25.6 & 22.8 & -2.80 & -10.9 & -0.07 & -3.4 \\
\hline Central-south & Risopatron & $\mathrm{W}$ & $1955-97$ & 5.4 & 4.9 & -0.53 & -9.8 & -0.01 & -0.64 \\
\hline Central-south & Olivares Gama & SW & $1955-97$ & 14.7 & 13.5 & -1.20 & -8.2 & -0.03 & -1.46 \\
\hline Central-south & G30 & $\mathrm{S}$ & $1955-97$ & 1.3 & 0.9 & -0.40 & -31.0 & -0.01 & -0.49 \\
\hline Central-south & G32 & $\mathrm{S}$ & $1955-97$ & 1.4 & 0.7 & -0.72 & -50.7 & -0.02 & -0.87 \\
\hline Central-south & Cipreses & $\mathrm{W}$ & $1955-97$ & 40.0 & 39.4 & -0.57 & -1.4 & -0.02 & -0.78 \\
\hline Central-south & Casa Pange & $\mathrm{N}$ & $1961-95$ & 7.0 & 6.4 & -0.60 & -8.6 & -0.02 & -0.9 \\
\hline Central-south & Blanco Chico & $\mathrm{W}$ & $1961-95$ & 7.0 & 6.6 & -0.40 & -5.7 & -0.01 & -0.6 \\
\hline Central-south & Verde & $\mathrm{S}$ & $1961-95$ & 8.1 & 8.0 & -0.13 & -1.6 & 0.00 & -0.2 \\
\hline Aysén-Magallanes & Cerro Blanco & $\mathrm{W}$ & $1945-97$ & 12.3 & 11.8 & -0.48 & -3.9 & -0.01 & -0.46 \\
\hline
\end{tabular}


Table 4. Thickness changes in glaciers of northern and centralsouth zones (source: this work)

\begin{tabular}{ccc}
\hline Gone & $\begin{array}{c}\text { Thinning } \\
\text { rate }\end{array}$ & $\begin{array}{c}\text { Measurement } \\
\text { period }\end{array}$ \\
$\mathrm{ma}^{-1}$ & \\
& & \\
\hline
\end{tabular}

Northern Tapado (accumulation area) No change 1955-99

Central-south Esmeralda (accumulation area) No change 1955-2000

$\begin{array}{llll}\text { Central-south Juncal Sur (ablation area) } & -1 & 1955-97\end{array}$

Central-south Olivares Gama (ablation area) $\quad-0.7 \quad 1955-97$

\begin{tabular}{llll} 
Central-south & G32 (ablation area) & -1.4 & $1955-97$ \\
\hline
\end{tabular}

These were analyzed with a stereoscope to determine the major characteristics and boundaries of the glaciers. The information obtained was transferred with a Zoom Transfer Scope to a standard topographic map compiled by IGM. Several satellite images have also been employed, especially Landsat TM images. These were georeferenced digitally by using a geographic information system (GIS) software package.

Another important source of information is historical data. These sources were studied, mapped, and related to the most recent topographic and glaciological parameters. In many cases, frontal positions analyzed within the study period were corrected with field data, especially where glacier termini were positioned with global positioning system (GPS) satellite receivers.

Because there are a very small number of glaciers with measured surface changes, we applied a loss ratio, according to the main glaciers of each zone:

1. Northern Chile: the loss ratio measured at Glaciar Tronquitos was applied to all of the glaciers inventoried in this zone.

2. Central-south Chile: the extent of 10 glaciers was photointerpreted to determine the original and final surfaces.

The mean area loss value was applied to all glaciers in the zone.

3. Aysén Magallanes: because the number of glacier studies of this zone is very small, we applied the mean value between the surface loss percentage of HPN and HPS.

4. HPN: data from Aniya (1999) were used.

5. HPS-Chile: data from Aniya (1999) were used.

\section{Ice thickness}

Ice-thickness measurements in Chile during the last few years have been carried out with radio-echo sounding methods (Rivera and others, 2000). Thickness changes were measured by several methods: analysis of aerial photographs from several dates with a parallax bar; comparison of digital terrain models (DTMs) with GIS; and theodolite and GPS measurements in the field.

Since there are very few ice-thickness measurements in Chile, a mean value for each of the five zones of the country was assigned to the inventoried glaciers according to their surface areas. This method follows Marangunic (1979), who determined a thickness scale suitable to all central Chilean glaciers based on published data on the Swiss Alps, Norway, the Canadian Arctic and North America (Post and others, 1971) (Table 1). Ice-thickness estimations were adjusted to previous measurements.

\section{Ice thinning}

1. In the northern Chile zone we measured the thinning rate for Glaciar Tapado, located at the summit of Cerro Tapado $\left(30^{\circ} 08^{\prime} \mathrm{S}, 69^{\circ} 55^{\prime} \mathrm{W}\right.$; Fig. 1).

2. In the central-south zone, thinning values were measured on four glaciers (Glaciares Esmeralda, Juncal Sur, Olivares Gama and G32; Fig. 1).

3 In the Aysén-Magallanes zone we estimated the minimum and maximum thinning rates based upon the values for HPN by Aniya (1999).

4. HPN: we used the value of Aniya (1999).

5. HPS-Chile: values of Aniya (1999) were considered, with a few modifications due to the thickening of Glaciar Pío XI not considered by Aniya.

In the zones where the glacier inventory includes information related to accumulation and ablation areas, a minimum thinning rate was applied to the accumulation areas, and the maximum rate to the ablation areas for each zone.

\section{Ice density}

To calculate the water equivalent of the total ice volume lost by thinning and retreat, we employed a mean density of 850 $\mathrm{kg} \mathrm{m}^{3}$, an acceptable value for temperate ice with a significant firn layer above the firn-ice interface (Yamada, 1987).

Table 5. Estimations of volume loss by region for Chilean glaciers during the study period

\begin{tabular}{|c|c|c|c|c|c|c|c|c|c|c|c|c|c|c|}
\hline \multirow[t]{3}{*}{ Zone } & \multirow{3}{*}{$\begin{array}{c}\text { Total } \\
\text { original } \\
\text { surface }\end{array}$} & \multirow{3}{*}{$\begin{array}{c}A A R \\
\\
\\
\%\end{array}$} & \multicolumn{2}{|c|}{$\begin{array}{c}\text { Estimated } \\
\text { thickness per zone }\end{array}$} & \multirow{3}{*}{$\begin{array}{c}\text { Mean } \\
\text { loss in } \\
\text { 51years } \\
\\
\%\end{array}$} & \multicolumn{2}{|c|}{$\begin{array}{l}\text { Volume lost by } \\
\text { retreat in last } \\
\text { 51 years }\end{array}$} & \multicolumn{2}{|c|}{ Thickness change } & \multicolumn{2}{|c|}{$\begin{array}{l}\text { Volume lost by } \\
\text { thinning in last } \\
\text { 51 years }\end{array}$} & \multicolumn{2}{|c|}{$\begin{array}{l}\text { Total volume lost } \\
\text { in last } 51 \text { years }\end{array}$} & \multirow[t]{3}{*}{ Source } \\
\hline & & & Min. & $\operatorname{Max}$ & & Min. & Max. & Accumulation area & Ablation area & Min. & Max. & Min. & $\operatorname{Max}$ & \\
\hline & & & $\mathrm{m}$ & $\mathrm{m}$ & & $\mathrm{km}^{3}$ & $\mathrm{~km}^{3}$ & $\mathrm{ma}^{-1}$ & $\mathrm{ma}^{-1}$ & $\mathrm{~km}^{3}$ & $\mathrm{~km}^{3}$ & $\mathrm{~km}^{3}$ w.e. & $\mathrm{km}^{3}$ w.e. & \\
\hline Northern & 116 & 56 & 30 & 50 & 11.4 & 0.4 & 0.7 & 0 & -0.7 to -1.4 & 2 & 4 & 2 & 4 & This work \\
\hline Central-south & 1300 & 44 & 50 & 130 & 12.8 & 8.3 & 21.6 & 0 & -0.7 to -1.4 & 26 & 52 & 29 & 63 & This work \\
\hline Aysén-Magallanes & 5300 & 68 & 100 & 200 & 1.65 & 8.7 & 17.5 & -0.3 & -0.5 to -1 & 98 & 142 & 92 & 135 & This work \\
\hline $\mathrm{HPN}$ & 4200 & 62 & 100 & 300 & 1.5 & 6.3 & 19.2 & -0.5 to -1 & -1 to -2 & 146 & 291 & 129 & 264 & Aniya (1999) \\
\hline HPS-Chile & 9659 & 75 & 200 & 400 & 1.8 & 34.8 & 69.5 & 0 to -1 & 2.2 to -3.0 & 233 & 607 & 227 & 575 & This work \\
\hline Total & 20575 & & & & & 58.5 & 128.5 & & & 505 & 1095 & 479 & 1041 & This work \\
\hline
\end{tabular}




\section{Study period}

We selected the period 1945-96 for this work, in order to standardize the measurements and obtain a common signal for the Chilean glaciers. This period was chosen mainly for the availability of data; it also matches the study period employed by Aniya, (1999). The beginning of the study period is based upon the date of the first aerial photographic survey of Chile, carried out by the United States Air Force, who generated a map at 1:250000 scale for most of the country. The end of the study period was based on the date of one of the last aerial photog raphic surveys of central Chile, carried out by the Chilean Air Force in 1996-97.

\section{Total volume contributed}

Adding the effect of surface loss, thinning and glacier retreat to the contribution to eustatic sea-level rise, the waterequivalent volume can be estimated as follows:

$$
V=S_{\mathrm{t}} f D E+A D S_{\mathrm{t}} \times 51,
$$

where $V$ is the water-equivalent volume contributed by a specific zone $\left(\mathrm{km}^{3}\right), S_{\mathrm{t}}$ is total glacier surfaces estimated or inventoried by zone $\left(\mathrm{km}^{2}\right), f$ is the ice-surface-loss factor for the study period by zone, calculated as original area/final area, $D$ is ice density $\left(\mathrm{kg} \mathrm{m}^{-3}\right), E$ is mean ice thickness for each zone $(\mathrm{km}), A$ is annual thinning rate $\left(\mathrm{m} \mathrm{a}^{-1}\right)$, applied with mean values for the accumulation and ablation areas per zone, according to the accumulation-area ratio (AAR) obtained from glacier inventories, and 51 is the number of years of the study period (1945-96).

\section{RESULTS}

Table 2 shows the frontal variations of the glaciers included in this study. Most of the glaciers are rapidly retreating.

Table 3 shows that surface shrinkage has occurred for all the analyzed glaciers, especially in the central-south zone. Although such changes are significant in terms of area values, major ice-surface losses have occurred throughout Patagonia.

Table 4 shows the thickness changes obtained for five glaciers. All the measurements carried out in the accumulation areas indicate no changes.

Table 5 shows all the parameters obtained and estimated for each zone, including AAR, minimum and maximum thickness, thickness changes and percentage of area lost in each zone.

\section{DISGUSSION}

\section{Climate-change relation}

It is likely that glacier recession is a response to climate warming, based on the following factors: (1) most of the glaciers described here are retreating at variable but significant rates; (2) the only glacier mass-balance measurements made in Chile have produced negative values (Escobar and others, 1995); and (3) the thickness changes detected are also negative. Nevertheless, non-climatic glacier responses do exist, especially for surging glaciers or tidewater glaciers (calving fronts), particularly Glaciar Pío XI (Rivera and others, 1997).

\section{Temperature rise}

In Chile, temperature trends have been evaluated by
Rosenblüth and others, (1997), who detected a warming rate of $1.3-2.0^{\circ} \mathrm{C}$ (100 years) $)^{-1}$ for the period 1933-92. This atmospheric warming has accelerated during the last three decades, at a rate that has been matched in Punta Arenas and Antofagasta, and exceeded in Punta Angeles (Fig. 1), with a warming rate of $3.8^{\circ} \mathrm{C}(100 \text { years })^{-1}$ for the period 1960-92. This warming is especially significant for minimum temperatures, for which Punta Angeles and Punta Arenas show the largest values.

\section{Long-term changes in precipitation}

Reduced precipitation is observed over the last 100 years in the north, central and southern zones of Chile. However, medium-term and long-term trends are less clear, with a wide interannual variability closely related to the $\mathrm{El} \mathrm{Niño-}$ Southern Oscillation (ENSO), especially in central Chile.

In the Norte Chico (Fig. 1), Downing and others (1994) determined a $30 \%$ reduction in rainfall in La Serena in the 20th century. In central Chile, Rutllant and Fuenzalida (1991) confirmed a close relationship between ENSO phenomena and pluviometric anomalies, with a significant increase in rainfall during a negative phase of the Southern Oscillation Index (SOI), and a significant decrease during positive phases of SOI. This relationship has generated positive mass balances for Glaciar Echaurren Norte in El Niño years, but the high frequency of La Niña events in the 1990s produced negative balances (Escobar and others, 1995).

In southern Chile, Rosenblüth and others (1995) showed that annual precipitation at Evangelistas and Bahía Felix stations (Fig. 1) was reduced almost monotonically by 1000 and $1400 \mathrm{~mm}$, respectively, during the 20th century; this represents an approximate $25-33 \%$ decrease over the 100 year period.

In eastern Patagonia, Ibarzabal and others (1996) detected a clear negative precipitation trend at Lago Argentino station, on the eastern side of HPS (Fig. 1).

\section{Medium-term rainfall anomalies}

Other stations in southern Chile, such as Punta Arenas, isla San Pedro, Cabo Raper, Puerto Aysén, isla Guafo and Ancud (Fig. 1), do not exhibit a clear precipitation trend, but present significant cycles with respect to positive pluviometric anomalies (Warren, 1993; Rosenblüth and others, 1995; Rivera and Casassa, 1999).

The occurrence of these anomalies has been related to glacier variations, demonstrating a strong link between advances of termini and positive-rainfall-anomaly cycles, with an estimated response time for HPN of 15-20 years (Winchester and Harrison, 1996) and for HPS of 10-25 years (Rivera and others, 1997). However, precipitation anomalies have not affected all glaciers equally, probably because of the complexity of glacier behaviour and local conditions.

With respect to the warming trend in almost all of Chile and the trend of rainfall decrease with a high interannual variability in central Chile and southern Patagonia, it is expected that glacier retreat will continue and will affect the majority of glaciers in the country.

\section{Contribution to global sea-level rise}

With the parameters described earlier (Tables 3-5), we estimate a water-equivalent volume contributed by Chilean glaciers for the studied period (1945-96) of $760 \pm 281 \mathrm{~km}^{3}$, 
Table 6. Contribution of Chilean glaciers to eustatic sea-level rise

\begin{tabular}{|c|c|c|c|c|}
\hline & \multicolumn{2}{|c|}{ Surface area } & $\begin{array}{l}\text { Contribution to } \\
\text { sea-level rise }\end{array}$ & \multirow[t]{2}{*}{ Source } \\
\hline & $\mathrm{km}^{2}$ & $\%$ & $\mathrm{mma}^{-1}$ & \\
\hline HPN and HPS-Chile & e 13859 & 2.04 & $0.032 \pm 0.013$ & 6.4 This work \\
\hline Rest of Chile & 6716 & 0.99 & $0.009 \pm 0.002$ & 1.8 This work \\
\hline Worldwide & 680000 & 100 & 0.5 & 100 Meier and Bahr (1996) \\
\hline
\end{tabular}

which corresponds to a mean annual global sea-level rise of $0.041 \pm 0.015 \mathrm{~mm} \mathrm{a}^{-1}$ (Table 6). The error estimate corresponds to one standard deviation for the mean maximum and minimum volume contributed.

In terms of each zone's contribution of meltwater to global sea-level rise in the studied period, glaciers in northern Chile contribute $0.4 \%$, central-south glaciers 6\%, Aysén and Magallanes $14.9 \%$, HPN 25.9\% and HPS-Chile 52.8\%.

The overall contribution of Chilean Andes glaciers to global sea-level rise is $8.2 \%$ of the total contributed by the mountain glaciers of the world, although in terms of surface area they represent only $3 \%$ of the glacier and icecap area (Meier and Bahr, 1996).

The above comparison implies that despite a smaller glacierized area, there is more melting and recession of glaciers in Chile than was estimated before. This confirms the hypothesis that global warming is having a stronger, more rapid effect on Chilean glaciers, especially in Patagonia, than in other parts of the world.

A large marginal error exists for our preliminary estimation of the contribution of Chilean glaciers to global sea-level rise. More detailed studies on glacier behaviour in this part of the world should be pursued to characterize the sea-level rise contribution from "small glaciers".

\section{ACKNOWLEDGEMENTS}

This work is part of Fondo Nacional de Ciencias y Tecnología (FONDECYT) Nos. 10009843 and 1980293. The assistance of J. Araos and A. Fernández with cartography and figures is acknowledged. P. Jirón and F. Cawkwell helped with the English translation of the manuscript. The comments and suggestions of R. S. Williams, Jr and two anonymous referees improved the manuscript. J. Bamber and the University of Bristol helped with travel expenses. The support of Centro de Estudios Científicos (CECS), Valdivia, Chile, is also acknowledged. CECS is a Millennium Science Institute.

\section{REFERENCES}

Aniya, M. 1988. Glacier inventory for the Northern Patagonia Icefield, Chile, and variations 1944/45 to 1985/86. Arct. Alp. Res., 20(2), 179-187.

Aniya, M. 1999. Recent glacier variations of the Hielo Patagónicos, South America, and their contribution to sea-level change. Arct. Antarct. Alp. Res., $31(2), 165-173$.

Aniya, M. 2001. Glacier variations of Hielo Patagónico Norte, Chilean Patagonia, since 1944/45, with special reference to variations between 1995/96 and 1999/2000. Bull. Glaciol. Res. 18, 55-63.

Aniya, M. and P. Skvarca. 1992. Characteristics and variations of Upsala and Moreno glaciers, southern Patagonia. Bull. Glacier Res. 10, 39-53.

Aniya, M., H. Sato, R. Naruse, P. Skvarca and G. Casassa. 1996. The use of satellite and airborne imagery to inventory outlet glaciers of the Southern Patagonia Icefield, South America. Photogramm. Eng. Remote Sensing, 62(12), 1361-1369.

Downing, T. and6 others. 1994. Climate change and sustainable development in the Norte Chico, Chile: climate, water resources and agriculture. Birmingham, University of Birmingham. School of Geography; University of Oxford, Environmental Change Unit Research Report 6. (Occasional Paper 35.)

Escobar, F., G. Casassa and V. Pozo. 1995. Variaciones de un glaciar de Montaña en los Andes de Chile Central en las últimas dos décadas. Bull. Inst. Fr. Étud. Andines (Lima), 24(3), 683-695.

Garín, C. 1987. Inventario de glaciares de los Andes Chilenos desde $10 \mathrm{l} 18^{\circ} \mathrm{a}$ $\operatorname{los} 32^{\circ}$ de latitud sur. Rev. Geogr. Norte Grande, 14, 34-48.

Holmlund, P. and H. Fuenzalida. 1995. Anomalous glacier responses to 20th century climatic changes in Darwin Cordillera, southern Chile. F. Glaciol., 41(139), 465-473.

Ibarzabal y Donángelo, T., J. A. J. Hoffmann and R. Naruse. 1996. Recent climate changes in southern Patagonia. Bull. Glacier Res. 14, 29-36.

Lliboutry, L. 1956. Nieves y glaciares de Chile: fundamentos de glaciología. Santiago, Ediciones de la Universidad de Chile.

Lliboutry, L. 1998. Glaciers of Chile and Argentina. In Williams, R. S. and J. G. Ferrigno, eds. Satellite image atlas of glaciers of the world. U.S. Geol. Surv. Prof. Pap. 1386-I, I109-I 206.

Marangunic, D. G. 1979. Inventario de glaciares en la hoya del Río Maipo. Santiago, Dirección General de Aguas. (Publicacion G-2.)

Meier, M. F. 1984. Contribution of small glaciers to global sea level. Science, 226(4681), 1418-1421.

Meier, M. F. and D. B. Bahr. 1996. Counting glaciers: use of scaling methods to estimate the number and size distribution of glaciers of the world. CRREL Spec. Rep. 96-27, 89-94.

Post, A., D. Richardson, W.V. Tangborn and F. L. Rosselot. 1971. Inventory of glaciers in the North Cascades, Washington. U.S. Geol. Surv. Prof. Pap. 705-A.

Rivera, A. and G. Casassa. 1999. Volume changes on Pio XI glacier, Patagonia: 1975-95. Global Planet. Change, 22(1-4), 233-244.

Rivera, A., H. Lange, J. C. Aravena and G. Casassa. 1997. The 20th-century advance of Glaciar Pio XI, Chilean Patagonia. Ann. Glaciol., 24, 66-71.

Rivera, A., G. Casassa, C. Acuña and H. Lange. 2000. Variaciones recientes de glaciares en Chile. Rev. Invest. Geogr., 34, 29-60.

Rosenblüth, B., G. Casassa and H. Fuenzalida. 1995. Recent climatic changes in western Patagonia. Bull. Glacier Res. 13, 127-132.

Rosenblüth, B., H. A. Fuenzalida and P. Aceituno. 1997. Recent temperature variations in southern South America. Int. F. Climatol., 17 (1), 67-85.

Rutllant, J. and H. Fuenzalida. 1991. Synoptic aspects of the central Chile rainfall variability associated with the Southern Oscillation. Int. F. Climatol., $11(1), 63-76$.

Warren, C. R. 1993. Rapid recent fluctuations of the calving San Rafael Glacier, Chilean Patagonia: climatic or non-climatic? Geogr. Ann., 75A (3), 111-125.

Winchester, V. and S. Harrison. 1996. Recent oscillations of the San Quintin and San Rafael Glaciers, Patagonian Chile. Geogr. Ann., 78A(1), 35-49.

Yamada, T. 1987. Glaciological characteristics revealed by 37.6-m deep core drilled at the accumulation area of San Rafael Glacier, the Northern Patagonia Icefield. Bull. Glacier Res. 4, 59-67. 